\title{
High Calorie/Osmolar Feeding and Hypertonic Dehydration
}

\author{
L. S. TAITZ and H. D. BYERS \\ From the Department of Child Health, University of Sheffield, Sheffield
}

Taitz, L. S., and Byers, H. D. (1972). Archives of Disease in Childhood, 47, 257. High calorie/osmolar feeding and hypertonic dehydration. Analysis of the sodium content of milk taken from bottles brought by mothers to feed their babies while waiting in the postnatal clinic indicates that the tendency to use excessive amounts of milk powder in feeds is widespread.

The effects of high solute/calorie feeding on osmolar loading, water intake, and urinary volume, and its potential risk are discussed.

In 3 cases of hypertonic dehydration the feeds given to the infants had contained excess calories and solute, because heaped scoops of milk powder instead of the recommended level measures had been used in preparing the formula.

A disturbing phenomenon in Britain at the present time is the high incidence of hypertonic dehydration among infants with dehydration secondary to gastroenteritis (Jacobs et al., 1970). In a recent series the number of infants with raised serum sodium concentrations was $63 \%$ (Ironside, Tuxford, and Heyworth, 1970). This is substantially higher than the usually quoted incidence (Cooke, 1969; Finberg, 1969). It is a serious disorder of infancy with a significant mortality and morbidity (Macauley and Watson, 1967), and is most commonly associated with gastroenteritis. The factors that lead to its occurrence are multiple, including relation of water to electrolyte loss, renal function, and the composition of the oral intake during the period of stress (Harrison and Finberg, 1959). The reasons for the apparent high incidence in Britain are not clear and it is the purpose of this communication to draw attention to the possible role of high osmol/calorie feeding in its pathogenesis.

\section{Material and Methods}

Samples of milk formula were obtained from mothers bringing their 6- to 10-week-old babies for routine postnatal check-up at the Jessop Hospital, Sheffield. The bottles had been prepared at home and brought to feed the infants while at the clinic. The mothers did not know that the sample was to be requested.

Thirty-two samples of full cream milk formula were collected and analysed for sodium content after homo-

Received 3 September 1971. genization on a vortex rotor. 10 control samples of full cream formula, collected from the milk kitchens of the Jessop Hospital and Children's Hospital or prepared in the laboratory according to the instructions of the manufacturers, were analysed for sodium content.

Random urine samples were taken from 15 artificially fed (whole cow's milk formula) and 19 breast fed infants attending the clinic. Osmolality, creatinine, urea, and uric acid concentrations were measured by standard techniques.

\section{Results}

The sodium content of the control samples ranged from 25 to $26 \cdot 8$ with a mean of $26 \mathrm{mEq} / \mathrm{l}$. The sodium contents of the samples obtained from the mothers ranged from 22 to $66 \mathrm{mEq} / \mathrm{l}$. with a mean of $32.6 \mathrm{mEq} / \mathrm{l}$. The difference between the means of $6.6 \mathrm{mEq} / \mathrm{l} .(25.4 \%)$ is statistically significant $(P<0.01)$. The distribution of sodium concentrations is shown in Table $I$.

The values of urine osmolality in breast fed infants ranged from 43 to 228 with a mean of 104.6 $\mathrm{mOsm} / \mathrm{kg}$ whereas those in artificially fed infants

\section{TABLE I}

Distribution of Sodium Concentrations of Milk Feeds Prepared by Mothers

\begin{tabular}{l|c|c|c|c|c}
\hline Sodium mEq/l. & 25 & $25-30$ & $30-35$ & $35-40$ & $\begin{array}{c}40 \text { or } \\
\text { more } \\
\text { Number of feeds }\end{array}$ \\
\hline
\end{tabular}


ranged from 67 to 1327 with a mean of $337 \cdot 9$ $\mathrm{mOsm} / \mathrm{kg} \quad(\mathrm{P}<0.001)$. Urine creatinine in breast fed infants ranged from 3 to 18 with a mean of $7.9 \mathrm{mg} / 100 \mathrm{ml}$, whereas in artificially fed infants it ranged from 10 to 34 with a mean of $16 \cdot 1 \mathrm{mg} /$ $100 \mathrm{ml} \quad(\mathrm{P}<0.001)$. The osmolar/creatinine ratio in breast fed infants was 13.4 and in artificially fed infants it was 23.4. The ratios of concentrations of osmols, creatinine, urea, and uric acid in artificially and breast fed babies are shown in Table III.

TABLE II

Urine Osmolality and Creatinine Concentrations of Breast Fed and Artificially Fed Infants

\begin{tabular}{|c|c|c|c|c|}
\hline \multicolumn{3}{|c|}{ Osmolality } & Creatinine & $\mathrm{Osm} / \mathrm{Cr}$ \\
\hline $\begin{array}{l}\text { Artificially } \\
\text { fed } \\
\text { Breast fed }\end{array}$ & $\begin{array}{l}\text { Range } \\
\text { Mean } \\
\text { Range } \\
\text { Mean }\end{array}$ & $\begin{array}{l}67-1327 \\
377 \cdot 9 \\
43-228 \\
104 \cdot 6\end{array}$ & $\begin{array}{r}16 \cdot 1 \\
7 \cdot 9\end{array}$ & $\begin{array}{l}23 \cdot 4 \\
13 \cdot 4\end{array}$ \\
\hline \multicolumn{3}{|c|}{$P<0.001$} & $P<0.001$ & \\
\hline
\end{tabular}

TABLE III

Mean Concentrations of Urea, Osmols, Uric Acid, and Creatinine in the Urines of Artificially Fed and Breast Fed Infants

\begin{tabular}{l|r|r|r}
\hline \multicolumn{1}{c|}{ Urine } & Artificially Fed & Breast Fed & AF/BF \\
\cline { 1 - 2 } Urea & $1007 \cdot 3$ & $211 \cdot 4$ & $4 \cdot 8$ \\
Osmol & $377 \cdot 9$ & $104 \cdot 0$ & $3 \cdot 6$ \\
Uric acid & $27 \cdot 3$ & $12 \cdot 1$ & $2 \cdot 3$ \\
Creatine & $16 \cdot 1$ & $7 \cdot 9$ & $2 \cdot 0$ \\
& & & \\
\hline
\end{tabular}

\section{Cases}

Case 1. A female aged 3 weeks weighing $3.7 \mathrm{~kg}$ was admitted with a 2-day history of screaming and anorexia. The infant was being fed with full cream powdered milk (Cow and Gate) in a concentration of 5 scoops to $5 \mathrm{oz}$ of water 5 times a day. She had had no diarrhoea or vomiting.

Investigations. $\mathrm{Hb} 17 \cdot 4 \mathrm{~g} / 100 \mathrm{ml}$, PCV $50 \%$, WBC's $18,800 / \mathrm{mm}^{3}$, polymorphs $50 \%$. Blood urea $185 \mathrm{mg} /$ $100 \mathrm{ml}$, sodium $166 \mathrm{mEq} / 1 ., p \mathrm{H} 7 \cdot 15, \mathrm{Pco}_{2} 52 \mathrm{mmHg}$, standard bicarbonate $15.5 \mathrm{mEq} / \mathrm{l}$. Faeces showed no pathogens. Urine, CSF, and nose and throat swab showed no growth.

A diagnosis of probable viral infection with hypertonic dehydration was made. The dehydration was thought to be due to fever and failure to feed. Intravenous therapy was begun and the child was given $N / 2$ saline $45 \mathrm{ml} / 2$ hours and then fifth normal saline. Within 12 hours the sodium was $154 \mathrm{mEq} / \mathrm{l}$. and the urea $140 \mathrm{mg} / 100 \mathrm{ml}$. By the next morning the sodium was $146 \mathrm{mEq} / 1$. and urea $72 \mathrm{mg} / 100 \mathrm{ml}$. The glucose was $100 \mathrm{mg} / 100 \mathrm{ml}$, and the calcium $10.0 \mathrm{mg} / 100 \mathrm{ml}$. After 48 hours the urea was $28 \mathrm{mg} / 100 \mathrm{ml}$, and the sodium $142 \mathrm{mEq} / \mathrm{l}$. The acid base state had also returned to normal. However, 6 hours after starting intravenous therapy the child had a convulsion which was treated with intravenous diazepam followed by intramuscular phenobarbitone and no further fits occurred. It was thought that the fit was related to the rapid correction of the dehydration and associated cerebral oedema. No further difficulty was encountered and the child was discharged apparently completely recovered. No diarrhoea was noted during her stay in hospital. She was seen again in outpatients one week later and on this occasion the mother admitted that she had used heaped scoops of milk powder in preparation of feeds before the illness.

Case 2. A male aged $2 \frac{1}{2}$ months weighing $5.3 \mathrm{~kg}$ was admitted with a 24-hour history of fever, irritability, and refusal of feeds. He had had no diarrhoea and had vomited only on one occasion. He was found to be febrile on admission and was noted to be extremely irritable. He had bilateral otitis media and appeared slightly dehydrated. He had been fed a full cream formula (Cow and Gate).

Investigations. $p \mathrm{H} 7 \cdot 38, \mathrm{PCO}_{2} 22 \mathrm{mmHg}$, bicarbonate $18 \mathrm{mEq} / \mathrm{l}$., CSF glucose $80 \mathrm{mg} / 100 \mathrm{ml}$. Serum sodium $160 \mathrm{mEq} / 1$. Potassium $6.0 \mathrm{mEq} / 1$. Blood urea $120 \mathrm{mg} / 100 \mathrm{ml}$. Plasma glucose $155 \mathrm{mg} / 100 \mathrm{ml}$. Calcium $8.6 \mathrm{mg} / 100 \mathrm{ml}$. Hb $12.6 \mathrm{~g} / 100 \mathrm{ml}$. PCV $40 \%$, WBC's $15,700 / \mathrm{mm}^{3}$, polymorphs $41 \%$.

A diagnosis of hypernatraemic dehydration secondary to his otitis media was made, and he was treated with penicillin and ampicillin, and with intravenous fluids for his dehydration. His condition improved gradually until about midday on the day of admission when he had a series of fits thought to be related to his hypernatraemia. Thereafter he made an uneventful recovery with return of the blood chemistry to normal within 48 hours. He developed mild diarrhoea on the 8th day of his admission and a growth of Esch. coli 086 from the faeces was reported. The diarrhoea was mild and because of the risk of spread of the infection he was discharged home.

Two weeks later the child was readmitted to hospital with mild diarrhoea. On this occasion he was again noted to be dehydrated with a serum sodium of 167 $\mathrm{mEq} / \mathrm{l}$. He responded well to intravenous fluids and made an uneventful recovery. When closely questioned the mother admitted that she had not obeyed instructions on the powdered milk packet and had been making up feeds with heaped scoops instead of levelled ones.

Case 3. A 6-day-old male weighing $3 \mathrm{~kg}$ who had been discharged from hospital on the second day of life, was admitted with a history that he had been off feeds for 2 days. 24 hours before admission he was noted to be dyspnoeic. He had had one loose stool 2 days before admission but had not vomited. The baby had been fed a full cream formula in the standard amounts but the scoops of milk powder had not been levelled with a knife as instructed. On examination the 
infant was desperately ill, grossly dehydrated, and tachypnoeic.

Investigations. Serum sodium was $174 \mathrm{mEq} / \mathrm{l}$., potassium greater than $10 \mathrm{mEq} / \mathrm{l}$., bicarbonate $7 \mathrm{mEq} / \mathrm{l}$. The blood urea was $340 \mathrm{mg} / 100 \mathrm{ml}$. The baby was rehydrated with hypotonic fluids with gradual return of the serum sodium and urea to normal. Generalized convulsions occurred on the second day but thereafter the child made an uneventful recovery.

\section{Discussion}

Several factors may contribute to the development of hypertonicity of the body fluids. It is probable that more than one factor is involved in most patients. Though diarrhoea is the most common association, it is not invariably present. Infection with fever, particularly infection of the respiratory tract with tachypnoea, may increase insensible water loss and thus produce hypertonicity. Chronic, apparently trivial, increased intake of osmols is a factor which may be more significant than is usually realized. Reference is made in several texts to the role of high solute feeds such a boiled skimmed or half cream milk or incorrectly diluted glucose-saline solutions (Berenberg, Mandell, and Fellers, 1969; Cooke, 1969; Finberg, 1969). The patients described here represent a more insidous and possibly more widespread example-the preparation of standard milk formulas containing excessive quantities of full cream dried milk powder.

Gross errors in formula preparation have long been known to result in hypertonic dehydration (Simpson and O'Duffy, 1967; Cochrane, 1965).

The importance of relatively small mistakes is not documented. In the cases reported here it is possible that the use of heaped measures of milk powder may have contributed to the subsequent development of hypernatraemia. The analysis of feeds shows that this tendency to prepare feeds of high solute content is widespread.

Ziegler and Fomon (1971) have recently reviewed the effects of high solute intake on water balance in infants. They have shown that the theoretical mean osmolar concentration of the urine in artificially fed infants is about $340 \mathrm{mOsm} / \mathrm{kg}$ of water which is 3 times greater than that expected in breast fed babies. The data presented in this study correspond closely with these predictions. The osmolar load per unit of creatinine excreted in artificially fed infants is nearly double that of breast fed infants. The ratios of osmolal and urea concentrations in artificially fed and breast fed infants are 4.8 and $3 \cdot 6$, respectively, whereas the creatinine and uric acid ratios are $2 \cdot 0$ and $2 \cdot 3$ respectively. As there is no reason to believe that cow's milk feeding leads to increased creatinine or uric acid output, it must be assumed that not only is there an increased excretion of osmols by the artificially fed babies but that the volume of urine produced by the artificially fed babies in this study is considerably smaller than breast fed babies, leading to the conclusion that their fluid intake is lower. This finding would be consistent with the observation of Ziegler and Fomon that infants fed ad libitum appear to regulate food intake largely on the basis of caloric needs. Therefore, volume of food (and consequently fluid) ordinarily decreases as caloric concentration of the formula is increased'. The data on sodium concentrations of milk formulas presented here indicate that their caloric content may be $25 \%$ higher than breast milk so that it would not be surprising if the volume of intake and therefore urine output was considerably lower. A $25 \%$ reduction of water intake would result in a $40 \%$ reduction in urine volume because insensible losses are relatively fixed. Widdowson and McCance (1970) have drawn attention to the potential value of random urine sample analysis as a means of assessing solute and water intake of groups of subjects, particularly used comparatively. The present study confirms the usefulness of this approach in a differing context.

It has been shown that high solute feeding regimens for young infants are associated with an increase in the capacity of the kidney to produce a concentrated urine (Edelmann and Barnett, 1960). Thus the normal healthy infant is well able to deal with the greatly increased solute and osmolar load of cow's milk as opposed to breast milk. The fact that this load is tolerated by most infants does not mean that it is desirable and, in the child with diarrhoea, sodium and protein loads in excess of that of cow's milk are hazardous. The study of Colle, Ayoub, and Raile (1958) showed that the administration of formulas containing a mixture of electrolyte and skimmed milk with sodium contents in excess of $40 \mathrm{mEq} / 1$. resulted in a greatly increased incidence of hypertonic dehydration.

High solute loads, which are well tolerated by the healthy well-hydrated infant without alteration of osmolar composition, may become dangerous in states of water depletion, partly because of the osmolar intake and partly because renal function has already been stretched by the osmolar load, thus reducing its reserve capacity. Furthermore, the reduced water intake implied by the data presented here may habituate mothers to offer diets 
of low water content placing babies at special risk during periods of increased water requirements. The careless preparation of feeds which results in solute and calorie concentrations substantially in excess of the recommended level which in itself is uncomfortably high must be considered a potential hazard to health.

I would like to thank Professor R. S. Illingworth and Dr. V. Dubowitz for helpful criticism and for permission to study these patients. This work was supported by MRC Grant No. G969/477/C. Professor J. Knowelden kindly provided the statistical analysis.

\section{REFERENCES}

Berenberg, W., Mandell, F., and Fellers, F. X. (1969). Hazards of skimmed milk, unboiled and boiled. Pediatrics, 44, 734.

Cochrane, W. A. (1965). Overnutrition in prenatal and neonatal life: a problem? Canadian Medical Association fournal, 93, 893.

Colle, E., Ayoub, E., and Raile, R. (1958). Hypertonic dehydration (hypernatremia): the role of feedings high in solutes. Pediatrics, 22, 5.

Cooke, R. E. (1969). Text Book of Pediatrics, 9th ed., p. 222. Edited by W. E. Nelson, V. C. Vaughan, and R. J. McKay. Saunders, Philadelphia.
Edelmann, C. M., Jr., and Barnett, H. L. (1960). Role of the kidney in water metabolism in young infants. fournal of ?.

Pediatrics, 56, 154 .
Finberg, L. (1969). Hypernatremia in infants as cause of brain $\overrightarrow{\bar{\omega}}$ damage. In Year Book of Pediatrics, 1969, p. 49 . Year Book Medical Publishers, Chicago.

Harrison, H. E., and Finberg, L. (1959). Hypernatremic dehydration. Pediatric Clinics of North America, 6, 193.

Ironside, A. G., Tuxford, A. F., and Heyworth, B. (1970). A $\frac{\mathcal{S}}{\partial}$ survey of infantile gastroenteritis. British Medical fournal, 3, 20.

Jacobs, S. I., Holzel, A., Wolman, B., Keen, J. H., Miller, V., 凹 Taylor, J., and Gross, R. J. (1970). Outbreak of infantile gastro-enteritis caused by Escherichia coli 0114. Archives of $O$ Disease in Childhood, 45, 656.

Macauley, D., and Watson, M. (1967). Hypernatraemia in infants $\vec{\omega}$ as cause of brain damage. Archives of Disease in Childhood, 42, 485.

Simpson, H., and O'Duffy, J. (1967). Need for clarity in infant feeding instructions. British Medical fournal, 3, 536.

Widdowson, E. M., and McCance, R. A. (1970). Use of random specimens of urine to compare dietary intakes of African and iv British children. Archives of Disease in Childhood, 45, 547.

Ziegler, E. E., and Fomon, S. J. (1971). Fluid intake, renal solute N load, and water balance in infancy. Fournal of Pediatrics, 78, N 561 .

Correspondence to Dr. L. S. Taitz, Department of $\stackrel{\circ}{=}$ Child Health, The Children's Hospital, Western Bank, Sheffield S10 2TH. 